Yüzüncü Y1l Üniversitesi
Tarim Bilimleri Dergisi

Araștırma Makalesi (Research Article)

Fruit Properties of Rose Hip (Rosa spp.) Genotypes Selected from Akkuş, Ordu Province $^{* *}$

\author{
Pınar İPEK ${ }^{1}$, Fikri BALTA ${ }^{2 *}$
}

${ }^{1}$ Ministry of Agriculture and Forest, Söke Agricultural Education Enterprise, Söke, Aydın, Turkey

${ }^{2}$ Ordu University, Faculty of Agriculture, Department of Horticulture, Ordu, Turkey

${ }^{1}$ https://orcid.org/0000-0002-4825-5489 2https://orcid.org/0000-0003-4414-8501

*Sorumlu yazar e-posta: baltaf04@yahoo.com

\section{Article Info}

Received: 27.01.2020

Accepted: 07.04.2020

Online Published 30.06.2020

DOI: 10.29133/yyutbd.680453

Keywords

Fruit,

Genotype,

Ordu,

Rose hip.
Abstract: In this study, fruit properties of 19 rose hip (Rosa spp.) genotypes selected from a large number of genotypes in the natural rose hip population in Akkuş district (Ordu province) in 2014-2015 were determined. The genotypes belonged to Rosa dumalis Bechst., Rosa gallica L. and Rosa canina species. They had a range of 1.22-3.47 $\mathrm{g}$ in fruit weight, 10.2-16.9 mm in fruit width, 13.2-25.2 $\mathrm{mm}$ in fruit length, 1.25-2.09 in fruit shape index, 62-72\% in fruit flesh ratio, 16-

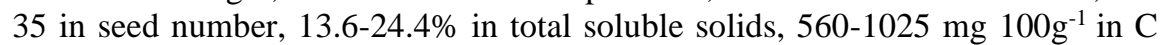
vitamin content, and 1.06-2.48 $\mathrm{Brix}^{\circ}$ in titratable acidity. The five genotypes were less thorny plants. The two genotypes (AK-75 and AK-20) were evaluated as promising in terms of fruit weight and fruit flesh ratio. In addition, AK-63 for TSS content and AK-16 for vitamin C content were found remarkable. Findings revealed that some genotypes could be valuable as genetic material for future breeding efforts.

\title{
Ordu ili Akkuş Yöresinden Seçilen Kuşburnu (Rosa spp.) Genotiplerinin Meyve Özellikleri
}

\section{Makale Bilgileri}

Geliş: 27.01.2020

Kabul: 27.04.2020

Online Yayınlanma 30.06.2020

DOI: $10.29133 /$ yyutbd.680453

\section{Anahtar kelimeler}

Meyve,

Genotip,

Ordu,

Kuşburnu.
Öz: 2014-2015 yıllarında yürütülen bu araştırmada, Ordu ili Akkuş yöresi doğal kuşburnu popülasyonunda çok sayıda genotip arasından seçilen 19 kuşburnu (Rosa spp.) genotipinin meyve özellikleri belirlenmiştir. Rosa dumalis Bechst., Rosa gallica L. ve Rosa canina türlerine ait olan genotiplerde meyve ağırlığ 1.22-3.47 g, meyve genişliği 10.2-16.9 mm, meyve uzunluğu 13.2-25.2 mm, meyve şekil endeksi 1.25-2.09, meyve eti oranı \%62-72, tohum sayıs 16-35, suda çözünebilir kuru madde miktarı 13.6-24.4 `briks, C vitamini içeriği 560-1025 mg $100 \mathrm{~g}^{-1}$ ve titre edilebilir asitlik \%1.06-2.48 aralığında değişim göstermiştir. Beş genotip az dikenli bulunurken, iki genotip (AK-75 ve AK-20) meyve ağırlığı ve meyve eti oranı açısından ümitvar olarak değerlendirilmiştir. Bunun yanında, suda çözünebilir kuru madde miktarı bakımından AK-63 ve C vitamini içeriği bakımından AK-16 dikkat çekici bulunmuştur. Bulgular, bazı genotiplerin gelecekteki ıslah çabaları için genetik materyal olarak değerli olabileceğini ortaya çıkarmıştır.

\footnotetext{
${ }^{* *}$ This study was obtained from M. Sc. thesis data.
} 


\section{Introduction}

Anatolia, where 25 Rosa species are grown, is among the natural spreading areas of Rosa species (Ercişli, 2005). Wild rose hip populations are distributed in all regions of Turkey, and they have a wide genetic diversity due to seed propagation and open pollination conditions since ancient times. These populations can contribute as valuable genetic resources to breeding programs aiming high yields, good fruit properties and resistance to diseases and pests (Çelik, 2007).

Rose hip, whose value is recognized in terms of human health, is in high demand today. Rose hip fruit contains natural antioxidants, minerals, carotenoids, bioflavonoids, tocopherol, fruit acids, vitamin C, pectin, tannin and amino acids (Ercişli, 2007). The chemical content of its fruit can vary to species, variety, genotype, growing ecology, altitude, harvest season and stage of fruit maturation. Rose hip is widely used in food, pharmacy and cosmetics industry (Y1ldız and Çelik, 2011). It is valued as a valuable raw material in the food and pharmaceutical industry in many European countries such as Russia, Germany, Switzerland and Finland. In these countries, rose hip fruit is used in fruit gel, baby food, fruit juice, marmalade and tea form, as an additive in pastry and confectionery industry, and also in vitamin-enrichment of other fruit and vegetable juices (Kızılc1, 2005; Dölek, 2008). In Turkey, rose hip is processed as fruit juice, marmalade, pulp and tea in factories and establishments in Gümüşhane, Erzincan and Tokat (Kızılc1, 2005).

Rose hip breeding programs are carried out in countries such as Bulgaria, Czechoslovakia, Germany, Russia and Sweden to develop commercial varieties. Our country is rich in rose hip genetic resources (Ercişli, 2005). In this respect, it is important to investigate the natural rose hip populations spreading to all regions and to select valuable genotypes with high yield and fruit quality. The first works on the selection of rose hip germplasm in Turkey started in 1990s, as a result of researches carried out up to the present many promising selections have been identified for yield and fruit characteristics. Although some studies on the registration of promising genotypes are still going on, there is yet no registered rose hip cultivar found in Turkey. On the other hand, rose hips grown in almost every region of our country are used as firewood in many places and this leads to the destruction of rose hip genetic resources.

The aim of this study was to select promising genotypes from the natural rose hip population in Akkuş district of Ordu province and to describe their fruit characteristics for future breeding efforts.

\section{Materials and Methods}

\subsection{Materials}

The material of the research consisted of wild rose hip plants growing in Akkus district of Ordu Province. Fruit samples were collected from wild plants during the harvest season. Akkuş district is surrounded by Kumru in the east, Erbaa and Çarşamba in the west, Terme and Ünye in the north and Niksar in the south. The mountains are covered with forests up to the peaks. The town center is located on a small plateau between the mountains at an altitude of 1300 meters. The district has no major rivers and lakes, but it has small creeks and streams. The most important of these is Tifi stream. The forest area corresponds to $65 \%$ of the overall surface area and is $412451 \mathrm{~km}^{2}$. Beech trees constitute $90 \%$ of the forest. A small amount of yellow pine and oak species are also available. Akkuş district has different climate structures. Inner Black Sea climate prevails in the northern part, continental (Central Anatolia) climate in the southern part and gate climate in the central part. Winters are hard and long, summers are short and cool. The average annual rainfall is $1000 \mathrm{~mm}$. The average cultivable land depth in the district is $50 \mathrm{~cm}$. Soil pH reaction is about 6-7.5. In general, soil structure is loamy (58\%) and clayey-loamy (42\%), barren, stony and weak features (Anonymous, 2017).

\subsection{Methods}

In order to determine the promising genotypes in the naturally grown rose hip population in the district, a large of of plants were investigated by observation before harvest season, and the plants marked according to the selection criteria such as fruit size, fruitfulness and thorn density were numbered. Each labeled plant was evaluated as a genotype. Fruit samples were taken from these plants 
during the harvest season. Care was taken not to collect fruit samples from plants with very small fruits, over-thorny, low fruitful, and disease and pest infestation. In the study, 106 wild rose hip plants were assessed within native population. At least 100 fruit samples were randomly taken from each of these plants during the harvest season. According to the fruit analyses of the first year, 30 genotypes with the lowest fruit weight and vitamin $\mathrm{C}$ contents were eliminated. Thus, the number of genotypes was reduced to 76 in the second year. All genotypes were compared to the Weighted Ranked Method (WRM) that based on 6 criteria such as fruit weight, fruit flesh ratio, vitamin C content, total soluble solids content, thorn density and fruitfulness (Akkuş, 2016; Ersoy and Özen, 2016). The 19 genotypes with the highest WRM scores were selected and their fruit characteristics were described. Fruit samples randomly collected from the genotypes were measured and analyzed in Ordu University Faculty of Agriculture Department of Horticulture. For genotypes, values of fruit weight, fruit width, fruit length, fruit flesh ratio, fruit shape, fruit shape index, seed weight, seed number, vitamin $\mathrm{C}$ content, titratable acidity (TA), total soluble solids (TSS) and $\mathrm{pH}$ were determined. The content of Vitamin C was quantified with the reflectometer set of Merck Co (Merck RQflex). In addition, fruit color, fruit shape, thorn density, fruitfulness, and fruit exterior pubescence were identified.

\section{Results}

Within the natural rose hip population at 1100-1300 m altitude in the district, 71 Rosa canina, 15 Rosa gallica L. and 20 Rosa dumalis Bechst. genotypes were examined for two years (in 20142015). Having the highest WRM scores, 19 genotypes were selected promising, and their fruit characteristics were identified in this study.

Table 1. Values of fruit weight, seed weight, seed number, fruit flesh weight, fruit flesh ratio, fruit length, fruit width, fruit shape index for 19 rose hip (Rosa spp.) genotypes selected from Akkuş, Ordu Province (2014-2015).

\begin{tabular}{|c|c|c|c|c|c|c|c|c|c|}
\hline Genotype & Species & $\begin{array}{c}\text { Fruit } \\
\text { Weight } \\
\text { (g) }\end{array}$ & $\begin{array}{c}\text { Seed } \\
\text { Weight } \\
\text { (g) }\end{array}$ & $\begin{array}{c}\text { Seed } \\
\text { Number }\end{array}$ & $\begin{array}{c}\text { Fruit } \\
\text { Flesh } \\
\text { Weight (g) }\end{array}$ & $\begin{array}{c}\text { Fruit Flesh } \\
\text { Ratio } \\
(\%)\end{array}$ & $\begin{array}{c}\text { Fruit } \\
\text { Length } \\
\text { (mm) }\end{array}$ & $\begin{array}{c}\text { Fruit } \\
\text { Width } \\
(\mathrm{mm})\end{array}$ & $\begin{array}{c}\text { Fruit } \\
\text { Shape } \\
\text { Index }\end{array}$ \\
\hline AK-75 & Rosa dumalis Bechst. & 3.47 & 0.99 & 28 & 2.48 & 71 & 25.2 & 16.9 & 1.48 \\
\hline AK-65 & Rosa dumalis Bechst. & 2.08 & 0.66 & 27 & 1.42 & 68 & 23.3 & 12.8 & 1.83 \\
\hline AK-36 & Rosa dumalis Bechst. & 1.73 & 0.47 & 21 & 1.26 & 71 & 20.6 & 12.5 & 1.63 \\
\hline AK-100 & Rosa dumalis Bechst. & 1.70 & 0.63 & 27 & 1.07 & 62 & 21.7 & 12.1 & 1.80 \\
\hline AK-82 & Rosa dumalis Bechst. & 1.58 & 0.54 & 25 & 1.04 & 65 & 17.8 & 12.7 & 1.41 \\
\hline AK-37 & Rosa dumalis Bechst. & 1.49 & 0.52 & 22 & 0.97 & 68 & 21.4 & 10.4 & 2.09 \\
\hline AK-86 & Rosa gallica L. & 2.17 & 0.75 & 35 & 1.42 & 65 & 19.8 & 14.5 & 1.37 \\
\hline AK-87 & Rosa gallica L. & 2.06 & 0.67 & 31 & 1.39 & 67 & 13.2 & 10.5 & 1.25 \\
\hline AK-16 & Rosa gallica L. & 1.71 & 0.57 & 27 & 1.14 & 65 & 18.5 & 12.9 & 1.42 \\
\hline AK-20 & Rosa canina & 2.04 & 0.58 & 24 & 1.46 & 71 & 20.7 & 13.4 & 1.55 \\
\hline AK-3 & Rosa canina & 2.22 & 0.83 & 32 & 1.39 & 63 & 19.8 & 14.7 & 1.34 \\
\hline AK-44 & Rosa canina & 1.78 & 0.53 & 21 & 1.25 & 71 & 19.2 & 13.0 & 1.48 \\
\hline AK-63 & Rosa canina & 1.72 & 0.49 & 22 & 1.23 & 71 & 20.2 & 13.0 & 1.56 \\
\hline AK-70 & Rosa canina & 1.62 & 0.43 & 16 & 1.19 & 72 & 20.8 & 11.6 & 1.79 \\
\hline AK-61 & Rosa canina & 1.68 & 0.55 & 23 & 1.13 & 68 & 22.2 & 12.0 & 1.83 \\
\hline AK-83 & Rosa canina & 1.66 & 0.55 & 24 & 1.11 & 66 & 20.2 & 12.4 & 1.61 \\
\hline AK-54 & Rosa canina & 1.54 & 0.44 & 17 & 1.10 & 71 & 18.6 & 12.5 & 1.47 \\
\hline AK-56 & Rosa canina & 1.45 & 0.46 & 20 & 0.99 & 68 & 18.9 & 12.1 & 1.56 \\
\hline AK-98 & Rosa canina & 1.22 & 0.40 & 19 & 0.82 & 68 & 17.4 & 10.2 & 1.70 \\
\hline
\end{tabular}

Values of fruit weight, seed weight, seed number, fruit flesh weight, fruit flesh ratio, fruit length, fruit width, fruit shape index recorded for promising genotypes were presented in Table 1. Fruit weight was recorded between $1.22 \mathrm{~g}$ and $3.47 \mathrm{~g}$. The six genotypes (AK-75, AK-20, AK-65, AK86, AK-3 and AK-87) had fruits over $2 \mathrm{~g}$. Seed weight changed between from $0.40 \mathrm{~g}$ to $0.99 \mathrm{~g}$. Genotypes produced 16-35 seeds per fruit. Fruit flesh weight varied between 0.82 to $2.48 \mathrm{~g}$. Fruit flesh ratio ranged from $62 \%$ to $71 \%$, and it was determined over $70 \%$ for seven genotypes. In addition, genotypes had a range of 13.2-25.2 mm for fruit length, 10.2-16.9 mm for fruit width and 1.25-2.09 for fruit shape index (Table 1). 
Table 2. The total soluble solids (TSS), vitamin C and titratable acidity (TA) values for 19 rose hip (Rosa spp.) genotypes selected from Akkuş district, Ordu Province (2014-2015).

\begin{tabular}{|c|c|c|c|c|}
\hline Genotype & Species & TSS $\left(\right.$ Brix $\left.^{\circ}\right)$ & TA (\%) & Vitamin C (mg 100g $\left.{ }^{-1}\right)$ \\
\hline AK-75 & Rosa dumalis Bechst. & 15.4 & 2.48 & 795 \\
\hline AK-65 & Rosa dumalis Bechst. & 21.2 & 1.73 & 750 \\
\hline AK-36 & Rosa dumalis Bechst. & 16.4 & 1.53 & 670 \\
\hline AK-100 & Rosa dumalis Bechst. & 17.8 & 1.17 & 710 \\
\hline AK-82 & Rosa dumalis Bechst. & 15.8 & 1.20 & 815 \\
\hline AK-37 & Rosa dumalis Bechst. & 18.0 & 1.81 & 745 \\
\hline AK-86 & Rosa gallica L. & 18.4 & 2.13 & 750 \\
\hline AK-87 & Rosa gallica L. & 13.6 & 1.06 & 770 \\
\hline AK-16 & Rosa gallica L. & 14.2 & 1.22 & 1025 \\
\hline AK-20 & Rosa canina & 17.8 & 1.32 & 725 \\
\hline AK-3 & Rosa canina & 15.4 & 1.79 & 945 \\
\hline AK-44 & Rosa canina & 15.4 & 2.07 & 885 \\
\hline AK-63 & Rosa canina & 24.4 & 2.05 & 560 \\
\hline AK-70 & Rosa canina & 21.2 & 1.91 & 905 \\
\hline AK-61 & Rosa canina & 14.2 & 1.18 & 815 \\
\hline AK-83 & Rosa canina & 14.8 & 1.11 & 860 \\
\hline AK-54 & Rosa canina & 16.6 & 1.61 & 845 \\
\hline AK-56 & Rosa canina & 14.0 & 1.08 & 765 \\
\hline AK-98 & Rosa canina & 22.3 & 1.88 & 760 \\
\hline
\end{tabular}

Table 3. Descriptions regarding fruitfulness, thorn density, fruit color, fruit shape and fruit exterior pubescence based on species for 19 rose hip (Rosa spp.) genotypes selected from Akkuş district, Ordu Province.

\begin{tabular}{|c|c|c|c|c|c|c|}
\hline Genotype & Species & Fruitfulness & $\begin{array}{l}\text { Thorn } \\
\text { Density }\end{array}$ & Fruit Color & Fruit Shape & $\begin{array}{c}\text { Fruit Exterior } \\
\text { Pubescence }\end{array}$ \\
\hline AK-75 & Rosa dumalis Bechst. & Medium & High & Orange & Oval & Absent \\
\hline AK-65 & Rosa dumalis Bechst. & Medium & High & Red & Conical & Absent \\
\hline AK-36 & Rosa dumalis Bechst. & Medium & High & Orange & Conical & Absent \\
\hline AK-100 & Rosa dumalis Bechst. & High & Medium & Orange & Conical & Absent \\
\hline AK-82 & Rosa dumalis Bechst. & Medium & Low & Orange & Oval & Absent \\
\hline AK-37 & Rosa dumalis Bechst. & High & High & Red & Cylindrical & Absent \\
\hline AK-86 & Rosa gallica L. & High & Low & Red & Round & Absent \\
\hline AK-87 & Rosa gallica L. & Low & Medium & Red & Round & Absent \\
\hline AK-16 & Rosa gallica L. & High & Medium & Orange & Oval & Absent \\
\hline AK-20 & Rosa canina & Medium & High & Orange & Oval & Absent \\
\hline AK-3 & Rosa canina & Medium & High & Orange & Round & Absent \\
\hline AK-44 & Rosa canina & Medium & High & Red & Oval & Absent \\
\hline AK-63 & Rosa canina & Medium & Medium & Red & Oval & Absent \\
\hline AK-70 & Rosa canina & Medium & High & Orange & Conical & Absent \\
\hline AK-61 & Rosa canina & High & Low & Orange & Conical & Absent \\
\hline AK-83 & Rosa canina & Low & Low & Orange & Conical & Absent \\
\hline AK-54 & Rosa canina & Medium & Medium & Red & Oval & Absent \\
\hline AK-56 & Rosa canina & High & Low & Orange & Oval & Absent \\
\hline AK-98 & Rosa canina & High & Medium & Red & Conical & Absent \\
\hline
\end{tabular}

The fruits of 19 rose hip selections contained TTS between 13.6 and 24. brix ${ }^{\circ}$. The content of total soluble solids was higher than \%20 in four genotypes (AK-63, AK-65, AK-70 and AK-98). The TA was determined between $1.06 \%$ and $2.08 \%$. $\mathrm{pH}$ value changed between 3.53-4.95. The content of

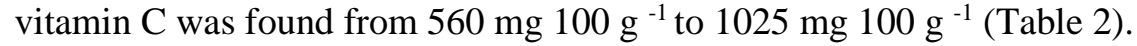

On the other hand, the species of rose hip selections were Rosa canina, Rosa dumalis Bechst. and Rosa gallica L. All selections had red and orange colored, and round, oval, conical and cylindrical shaped fruits. The pubescence of fruit exterior was absent for all selections. While the density of thorn was observed as low, medium and high, it was low for five genotypes (AK-56, AK-61, AK-82, AK-83 and AK-86). Plant fruitfulness was evaluated as high for seven genotypes (AK-16, AK-37, AK-56, AK-61, AK-86, AK-98 and AK-100), medium for ten genotypes and low for two genotypes (Table 3). 


\section{Discussion}

As it is known, fruit size, high fruit flesh ratio, high contents of dry matter and vitamin C, fruitfulness and thornless plant, suitability for mechanical harvest, easy propagation, resistance to disease and damages are emphasized as important characters for rose hip cultivar breeding efforts (Çelik, 2007).

In Turkey, many studies were conducted on native rose hip genetic resources in different areas, several fruit and plant characteristics were identified for many genotypes (Ercişli and Eşitken, 2004; Türkben et al., 2005; Doğan and Kazankaya, 2006; Çelik at al., 2009; Sağır, 2010; Güneş, 2011; Yıldız and Çelik, 2011; Ekincialp and Kazankaya, 2012; Çelik et al., 2015; Akkuş, 2016; Ersoy and Özen, 2016). In this study carried out in the wild rose hip population of Akkuş (Ordu province), fruit and some plant characteristics of 19 promising genotypes selected according to the selection criteria were identified.

In developing rose hip cultivar suitable for the industry, cultivars with large-sized fruits and high fruit flesh ratio are desired (Çelik et al., 2009). In this study, the promising genotypes exhibited a range of 1.22-3.47 g for fruit weight and $62-72 \%$ for fruit flesh ratio. For some rose hip (Rosa spp.) genotypes from different areas in Turkey, the range of fruit weight and fruit flesh ratio were reported as 3.14-4.80 g and 63.1-71.1\% from Erzurum (Ercişli and Eşitken, 2004), 2.04-6.10 g and 46.8-79.9 from Bitlis, Hakkâri and Van regions (Kazankaya et al., 2005), 2.21-6.16 g and 61.3-80.4\% from Gumushane and Erzincan (Kızılc1, 2005), 1.37-3.04 g and 45.8-79.4\% from Amasya (Dölek, 2008), 1.79-4.95 g and 66.4-100\% from Lake Van Basin (Çelik et al., 2009), 1.65-2.78 g and 63.8-75.0 from Akıncılar, Sivas (Sağır, 2010), 1.82-4.09 g and 55.2-85.0 from Muradiye (Yıldız and Çelik, 2011), 1.52-3.92 g and 59.3-76.6 from Hakkari (Ekincialp and Kazankaya, 2012), 1.44-4.69 g and 60-79 from Hamur, Ağrı (Akkuş, 2016), 1.40-2.77 g and 64-9-82.8\% (Ersoy and Özen, 2016), respectively. In addition, Cheikh-Affene et al. (2013) reported that rose hip genotypes (Rosa spp.) from Tunisia had a range of 0.9-1.9 $\mathrm{g}$ for fruit weight and 63.6-73.7\% for fruit flesh ratio. Soare et al. (2015) recorded 1.17-2.86 g fruit weight for rose hip genotypes (Rosa spp.) from Romania. It is possible to establish various similarities between the promising genotypes of this study and some rosehip genotypes and selections mentioned in the above studies. The values of fruit weight and fruit flesh ratio determined in some studies seem higher than those of this research. In this study, AK-75 was remarkable in terms of fruit weight (3.47 g) and fruit flesh ratio (71\%). Promising genotypes had smaller fruits than those of most research above.

It has been reported that the chemical composition of rose hip fruit could be affected by many factors such as species, cultivar, genotype, growing ecology, altitude, harvest time and maturation stage (Ercişli, 2007; Çelik et al., 2009; Akkuş, 2016).

Due to its high vitamin C content, which is regarded as criteria of selection for cultivar breeding efforts, rosehip is used not only for making marmalade and juice, but also as additive material to enrich the vitamin C content of several fruit juices (Çelik et al., 2009). The promising

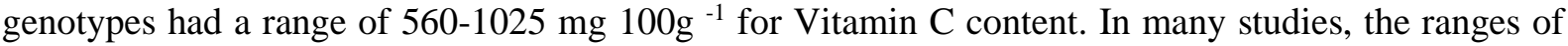
vitamin C content per $100 \mathrm{~g}$ fresh weight for rosehip genotypes and selections were reported as 1074$2557 \mathrm{mg}$ (Ercişli and Eşitgen, 2004), 301-1183 mg (Kazankaya et al., 2005), 305-945 mg (Kızılc1, 2005), 108-908 mg (Dölek, 2008), 517-1032 mg (Çelik et al., 2009), 438-766 mg (Sağır, 2010), 616$867 \mathrm{mg}$ (Rosu et al., 2011), 330-535 mg (Y1ldız and Çelik, 2011), 414-916 mg (Ekincialp and Kazankaya, 2012), 372-737 mg (Cheikh-Affene at al., 2013), 332-1603 mg (Ersoy and Özen, 2013), 53-563 mg (Soare et al., 2015), 540-1315 mg (Akkuş, 2016) and 402-511 mg (Alp et al., 2016). Many selected genotype of this study had vitamin C content similar to those of related studies.

TSS content of the selected genotypes varied between $13.6 \%$ and $24.4 \%$. For rose hip (Rosa spp.) genotypes from different areas, TSS ranges were reported as 31-36.7\% (Ercişli and Eşitgen, 2004), 14.8-36.2\% (Kazankaya et al., 2005), 14-30.8\% (K1zılc1, 2005), 22-40\% (Türkben et al., 2005), 15.9-32.8\% (Dölek, 2008), 17.7-28.4\% (Çelik et al., 2009), 23.2-33.9 (Sağır, 2010), 11.5-17.6\% (Rosu et al., 2011), 15-26.2\% (Yıldız and Çelik, 2011), 14.2-27.5\% (Ekincialp and Kazankaya, 2012), 24.130.5\% (Ersoy and Özen, 2013), 10-18\% (Soare et al., 2015), 9-32\% (Akkuş, 2016) and 17.6-22.8\% (Alp et al., 2016). In addition, the promising selections had a range of 1.06-2.48\% for TA. The range of TA for numerous many rose hip (Rosa spp.) genotypes were recorded as 1.25-3.23\% (K1z1lc1, 2005), 0.66-0.85\% (Doğan and Kazankaya, 2006), 1.09-2.50\% (Dölek, 2008), 0.67-1.89\% (Sağır, 
2010), 1.38-3.50\% (Yıldız and Çelik, 2011), 1.4-3.6\% (Soare et al., 2015), 0.05-0.22\% (Akkuş, 2016) and $0.04-1.55 \%$ (Ersoy and Özen, 2016). The findings on TSS and TA contents were in agreement with above many literatures.

On the other hand, the productivity and thorny status of the rose hip plant are also among the valuable characters for the variety breeding efforts (Ercişli and Eşitgen, 2004; Çelik, 2007). In this study, the thorny density was high for 8 genotypes, medium for 5 genotypes and low for 5 genotypes. In the researches conducted on the genetic resources in Turkey, numerous few, medium and very thorny and fruitful rose hip genotypes have been identified. In addition, a small number of thornless genotypes have also been reported (Ercişli and Eşitken, 2004; Çelik et al., 2009; Çelik et al. 2015; Akkuş, 2016).

As an excellent resource of rose hip genetic material, the diversity could contribute to future breeding efforts that aim at the valuable traits, such as high yield, fruit characteristics, bioactive compounds, and resistance to disease and pests (Sanderson and Fillmore, 2010). The results indicated genetic variation in the native rosehip germplasm of the district.

\section{Conclusion}

Rosehip, which has a wide spreading area in the world, has started to draw attention with the studies carried out in recent years. Turkey are rich in rose hips genetic resources. In this study, 19 rose hip genotypes selected from Akkuş district of Ordu were described. The two genotypes (AK-75 and AK-20) were evaluated as promising in terms of fruit weight and fruit flesh ratio. In addition, AK-63 for TSS content and AK-16 for vitamin C content were found remarkable. The data obtained from the genotypes are the values reached in natural land conditions. In this respect, the repeated trials are needed under controlled conditions in order to reveal the true values of genotypes. Some genotypes could be valuable as genetic material for future breeding efforts.

\section{Acknowledgment}

This research was produced from the findings of the project numbered TF-1626 supported by Ordu University Scientific Research Projects Unit (ODU-BAP). We thank the Ordu University Scientific Research Projects Unit (ODU-BAP) for its financial support.

\section{References}

Akkuş, E. (2016). Hamur (Ăgrı) Yöresinde doğal olarak yetişen Kuşburnu genotiplerinin (Rosa spp.) morfolojik tanımlanması. ODÜ Fen Bilimleri Enstitüsü, Bahçe Bitkileri Anabilim Dalı, Yüksek Lisans Tezi, Ordu.

Alp, Ş., Ercişli, S., Jurikova, T., Çakır, Ö, \& Gömlekçi, Ş. (2016). Bioactive content of rose hips of different wildly grown Rosa dumalis genotypes. Not. Bot. Hort. Agrobo, 44, 2, 472-476.

Anonymous. (2020). http://www.akkus.gov.tr/tarihi-ve-cografi-yapisi. Erişim tarihi: 22.01.2020

Cheikh-Affene, Z.B., Haouala, F., Trabelsi, N., Boulaaba, M., Ksouri, R., \& Harzallah-Skhiri, F. (2013). Pomological description and chemical composition of rose hips gathered on four Rosa species section Caninae growing wild in Tunisia. International Journal of Agricultural Science and Technology, 1, 3, 43-50.

Çelik F. (2007). Vangölü Havzası Kuşburnu (Rosa spp.) Genetik Kaynaklarının Seleksiyonu ve Mevcut Biyolojik Çeşitliliğin Tespiti. YYÜ Fen Bilimleri Enstitüsü, Bahçe Bitkileri Anabilim Dalı, Doktora Tezi, Van.

Çelik, F., Kazankaya, A., \& Ercişli, S. (2009). Fruit characteristics of some selected promising rose hip (Rosa spp.) genotypes from Van region of Turkey. Afric. Jour. Agric. Res., 4, 3, 236-240.

Çelik, F., Kazankaya, A., Doğan, A., Gündoğdu, M., \& Cangi, R. (2015). Some pomological and biochemical properties of rose hip (Rosa spp.) germplasm. Acta Horticulturae, 1089, 287-292.

Doğan, A., \& Kazankaya, A. (2006). Fruit properties of rose hip species grown in Lake Van Basin (Eastern Anatolia Region). Asian Journal of Plant Sciences, 5, 1, 120-122. 
Dölek, Ü. (2008). Bazı Kuşburnu (Rosa spp.) türlerinde optimal hasat zamanın ve fitokimyasal değişimlerin belirlenmesi. GOP Üniversitesi Fen Bilimleri Enstitüsü Bahçe Bitkileri Anabilim Dal1, Doktora Tezi, Tokat.

Ekincialp, A., \& Kazankaya, A. (2012). Hakkari yöresi kuşburnu genotiplerinin (Rosa spp.) bazı fiziksel ve kimyasal özelliklerinin belirlenmesi. Yüzüncü Yıl Üniversitesi Tarım Bilimleri Dergisi, 22, 1, 7-11.

Ercişli, S., \& Eşitken, A. (2004). Fruit characteristics of native rose hip (Rosa spp.) selections from the Erzurum province of Turkey. New Zealand Journal of Crop and Horticultural Sci., 32, 51-53.

Ercişli, S. (2005). Rosa (Rosa spp.) germplasm resources of Turkey. Genetic Resources and Crop Evolution, 52, 787-795.

Ercişli, S. (2007). Chemical composition of fruits in some rose (Rosa spp.) species. Food Chemistry, 104, 1379-1384.

Ersoy, N., \& Özen, M.S. (2016). Some physico-chemical characteristics in fruits of rose hip (Rosa spp.) genotypes from Bolu province in western part of Turkey. Agro-knowledge Journal, 17, 2, 191-201.

Güneş, S. (2011). Ümitvar bir kuşburnu (Rosa canina) genotipinin farklı iki lokasyondaki fenolojik, morfolojik ve pomolojik özellikleri. GOP Üniversitesi, Fen Bilimleri Enstitüsü, Bahçe Bitkileri Anabilim Dalı, Yüksek Lisans Tezi, Tokat.

Kazankaya, A., Türkoğlu N., Yılmaz M., \& Balta, M. F. (2005). Pomological description of Rosa canina selections from eastern Anatolia, Turkey. International J of Botany, 1, 11, 100-102.

Kızılcı, G. (2005). Bazı ümitvar kuşburnu (Rosa spp.) tiplerinin Erzincan ekolojik koşullarında adaptasyonu (Seleksiyon II). GOP Üni. Fen Bilimleri Enstitüsü, Yüksek Lisans Tezi, Tokat.

Rosu, C.M., Manzu, C., Olteanu, Z., Oprica, L., Oprea, A., Ciornea, E., \& Zamfirache, M.M. (2011). Several fruit characteristics of Rosa sp. genotypes from the northeastern region of Romania, Not Bot Horti Agrobo, 39, 2, 203-208.

Sağır, S. (2010). Akıncılar Yöresinde doğal olarak yetişen kuşburnuların (Rosa spp.) seleksiyon yoluyla sslahı. ODÜ Fen Bilimleri Enstitüsü, Bahçe Bitkileri Anabilim Dalı. Yüksek Lisans Tezi, Ordu.

Sanderson, K., \& Fillmore, S. (2010). Evaluation of native rose selections for rose hip production in Prince Edward Island. International Journal of Fruit Science, 10, 379-389.

Soare, R., Bonea, D., Iancu, P., \& Manila, G. (2015). Biochemical and technological properties of Rosa canina L. fruits from spontaneous flora of Oltenia, Romania. BulletinUASVM Horticulture, 72, 1, 182-186.

Türkben, C., Barut, E., Çopur, Ö, U., Durgut, E., \& Himelrick, D. G. (2005). Evaluation of rose hips (Rosa spp.) selections. International Journal of Fruit Science, 5, 2, 113-121.

Yıldız, Ü., \& Çelik, F. (2011). Muradiye (Van) yöresinde doğal olarak yetişen kuşburnu (Rosa spp.) genetik kaynaklarının bazı fiziko-kimyasal özellikleri. YYÜ Fen Bilimleri Enstitüsü Dergisi, 16, 2, 45-53. 